\title{
Treatment of Severe Diabetes Mellitus by Insulin Infusion
}

\author{
WARREN KIDSON, JOHN CASEY, EDWARD KRAEGEN, LESLIE LAZARUS
}

British Medical fournal, 1974, 2, 691-694

\section{Summary}

A new and simple form of insulin therapy for diabetic hyperglycaemia and ketoacidosis has been developed using a continuous intravenous infusion of insulin at a rate of $2.4 \mathrm{U} / \mathrm{hr}$ to maintain serum insulin concentration at physiological levels. This rate raises the mean serum insulin to $83 \mu \mathrm{U} / \mathrm{ml}$ and has a therapeutic effect which is not augmented by higher infusion rates. The response to such low doses of insulin indicates a need for a reappraisal of currently held theories about insulin resistance in diabetic ketoacidosis. In 11 diabetic patients with a mean plasma glucose of $514 \mathrm{mg} /$ $100 \mathrm{ml}$ this therapy produced continuous falls in plasma glucose at a mean rate of $75 \mathrm{mg} / 100 \mathrm{ml} / \mathrm{hr}$, and 10 out of 11 patients recovered within eight hours. This form of therapy is simple to institute, not complicated by hypoglycaemia, and avoids the confusion and empiricism of previously described forms of therapy.

\section{Introduction}

Ketoacidosis and acute severe hyperglycaemia remain important causes of morbidity and mortality in diabetes mellitus despite the availability of insulin for more than 50 years (Bradley, 1971).

Resistance to insulin action is said to exist in this condition as a result of inhibition of glucose utilization by ketones (Williamson and Krebs, 1961; Randle, 1965) and acidosis (Walker et al., 1963) and as a result of antibody binding of insulin (Yalow and Berson, 1961). Large doses of insulin have been recommended in an attempt to overcome insulin resistance. Initial doses of 40-400 units (Williams, 1968; Steinke and Thorn, 1970; Bradley, 1971; Winegrad and Clements, 1971), generally half subcutaneously and half intravenously, are given to achieve total doses of between $300-500$ units in six to 24 hours (Danowski, 1970). Some authors recommend that the initial insulin doses should be given intravenously only (Bondy, 1971; Rabinowitz et al., 1972), warning that subcutaneous insulin may be poorly absorbed in the presence of dehydration and impaired peripheral perfusion. Others (Sheldon and Pyke, 1968), however, recommend the simultaneous use of both routes of insulin administration because intravenously administered insulin has a shont plasma half life of four to five minutes (Turner et al., 1971; Sonksen et al., 1972), and the serum insulin concentration falls to less than $1 \%$ of the initial peak value after 25 minutes.

In general it is rane for any one treatment regimen to have been recommended by more than one group of authors. The treatment of diabetic ketoacidosis is clouded by a confusion of insulin dosages and administration routes.

The continuous infusion of insulin intravenously should overcome the problems of poor peripheral absorption after the

\footnotetext{
Garvan Institute of Medical Research, St. Vincent's Hospital, Sydney 2010, Australia

WARREN KIDSON, M.B., M.R.A.C.P., Research Fellow JOHN CASEY, PH.D., F.R.A.C.P., Staff Endocrinologist EDWARD KRAEGEN, B.SC., PH.D., Senior Research Officer LESLIE LAZARUS, M.B., F.R.A.C.P., Director
}

subcutaneous injection of insulin and the rapid decline in serum insulin concentration after intravenous bolus injection of insulin. The intravenous infusion of insulin in glucose solutions has been used for more than a decade in the management of the diabetic undergoing surgery (Galloway and Shuman, 1963; Beaser, 1970). Recently Genuth (1973) has successfully treated ketoacidotic diabetics with a high dose continuous insulin infusion in a glucose solution. Insulin given in this manner is variably adsorbed on to glassware (Ferrebee et al., 1951) and polyethylene tubing (Weisenfeld et al., 1968) though such binding can be reduced to less than $15 \%$ by the addition of human serum albumin to the infusion solution in a concentration of at least $0.35 \%$ (w/v) (Weisenfeld et al., 1968). Degradation of insulin with loss of biological activity is also possible with this form of administration.

Interest in intravenous insulin infusion has recently been reawakened by Sonksen et al. (1972), who have treated patients with varying degrees of hyperglycaemia and ketoacidosis by a continuous infusion of small doses of insulin. Their findings cast doubt on the actual extent of insulin resistance in diabetic ketoacidosis. Such doubt is supported by Alberti et al. (1973), who have treated diabetic ketoacidosis with repeated hourly intramuscular injections of 5-10 units of insulin. The rates of insulin administration used in these studies are greater than the daily pancreatic secretory rate but they are much smaller than the doses mentioned earlier.

The absorption of insulin from intramuscular sites seems to be less affected than absorption from subcutaneous sites by dehydration and shock (Alberti et al., 1973).

Profound hypoglycaemia is an uncommon complication during the treatment of ketoacidosis, but it poses a serious threat to the patient who has not already recovered consciousness and to the patient with ischaemic heart disease. In view of the short plasma half life of intravenously administered insulin hypoglycaemia should be more readily reversed in patients receiving continuous intravenous infusions of insulin which can be ceased at will than in patients who have received intermittent insulin either subcutaneously, intramuscularly, or intravenously, particularly when large doses have been given by these three routes.

The purpose of this study was to examine the use of low dose intravenous insulin infusion as a routine method of treatment for diabetic hyperglycaemia and ketoacidosis and to determine the optimum insulin dosage for such therapy.

\section{Patients and Methods}

Eleven diabetic patients with a mean age of 38 years (range 12-68 years) were treated on 12 occasions, one patient having been treated twice. Four of these patients were diagnosed as diabetic at the time of this presentation. Three of the seven known diabetics had received daily insulin therapy while four had not previously received insulin.

At the time of hospital admission for this illness plasma glucose, serum electrolytes, and urinary ketones were measured. Arterial blood gas and acid base studies were performed in most patients but quantitative or semi-quantitative estimates of plasma ketones were not performed.

Intravenous fluid and electrolyte replacement was begun with either physiological saline or Hartman's solution. Potassium chloride was added to these solutions when the 
patient had an adequate urinary output and the plasma glucose was falling. Sodium bicarbonate was not given to any patient. Coexisting or precipitating illness was also treated.

At the time of biochemical diagnosis of hyperglycaemia an intravenous loading dose of 0.5 units of neutral insulin (Actrapid, Novo) was given over five minutes, this dose being enough to raise the serum insulin by $30-80 \mu \mathrm{U} / \mathrm{ml}$. The intravenous insulin infusion was then begun at a rate of 20 or $40 \mathrm{mU} / \mathrm{min}$ - that is, 1.2 or $2.4 \mathrm{U} / \mathrm{hr}-$ from a syringe pump or controlled paediatric drip set. In some cases the infusion rate was increased to 80 or $160 \mathrm{mU} / \mathrm{min}$-that is, 4.8 or $9.6 \mathrm{U} / \mathrm{hr}$. The solution delivering the insulin intravenously consisted of physiological saline containing $1-2 \%$ human serum albumin to prevent insulin adsorption on to plastic tubing or glass. This solution was infused into a separate antecubital vein if serum was to be collected for insulin assay or else into the rehydration drip from a side arm.

The insulin infusion was stopped when the plasma glucose had fallen to the normal range or after eight hours if the plasma glucose had not fallen below $200 \mathrm{mg} / 100 \mathrm{ml}$.

Serial venous blood samples were collected at regular intervals, varying between 10 and 30 minutes, for serum glucose estimation by the autoanalyser modification of the ferricyanide method (Hoffman, 1937) in all cases and for serum immunoreactive insulin estimation (Hales and Randle, 1963) in eight cases. Serum potassium and other electrolyte estimations were performed at regular intervals.

\section{Results}

The mean plasma glucose of our patients at the time of admission was $514 \mathrm{mg} / 100 \mathrm{ml}$. Data on their pretreatment condition and response to treatment are given in the table.

In seven patients there was a significant fall in plasma glucose ranging from 61 to $157 \mathrm{mg} / 100 \mathrm{ml}$ during the initial period of partial rehydration before insulin infusion (see fig. 1) similar to that noted by Alberti et al. (1973).

The intravenous insulin infusions resulted in raised levels of serum immunoreactive insulin, the extent of the rise being dependent on the rate of insulin administration. Infusion rates of 20,40 , and $80 \mathrm{mU} / \mathrm{min}$ produced mean serum insulin concentrations of 38,83 , and $>200 \mu \mathrm{U} / \mathrm{ml}$ respectively in patients who had not previously received insulin.

The insulin infusion resulted in a continuous decline in plasma glucose in all patients at a mean rate of $75 \mathrm{mg} / 100$ $\mathrm{ml} / \mathrm{hr}$. The rate of decline in plasma glucose was roughly linear but showed no correlation with serum insulin concentration $(P>0.05)$, presence of acidosis, or a history of

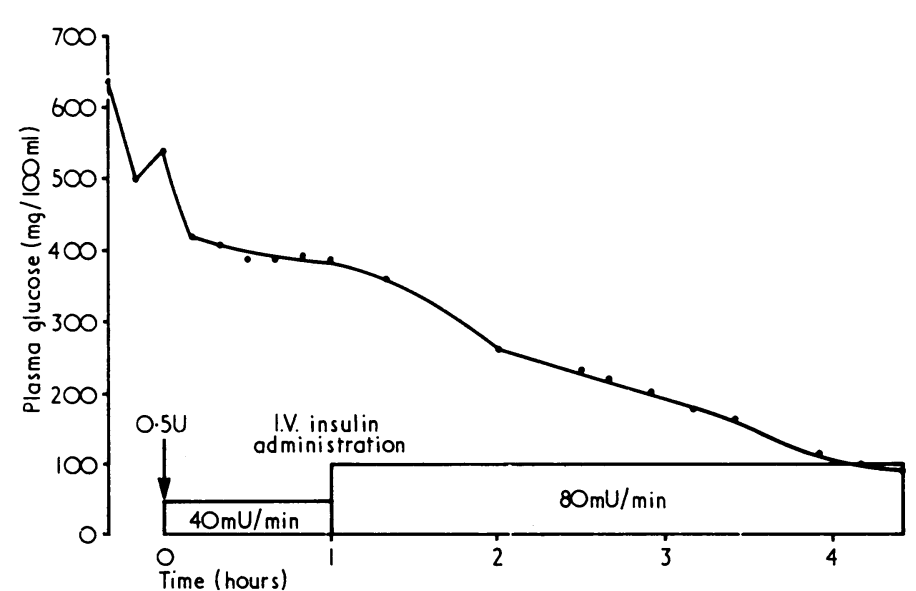

FIG. 1-Plasma glucose response to rehydration and insulin infusion in Case 4.

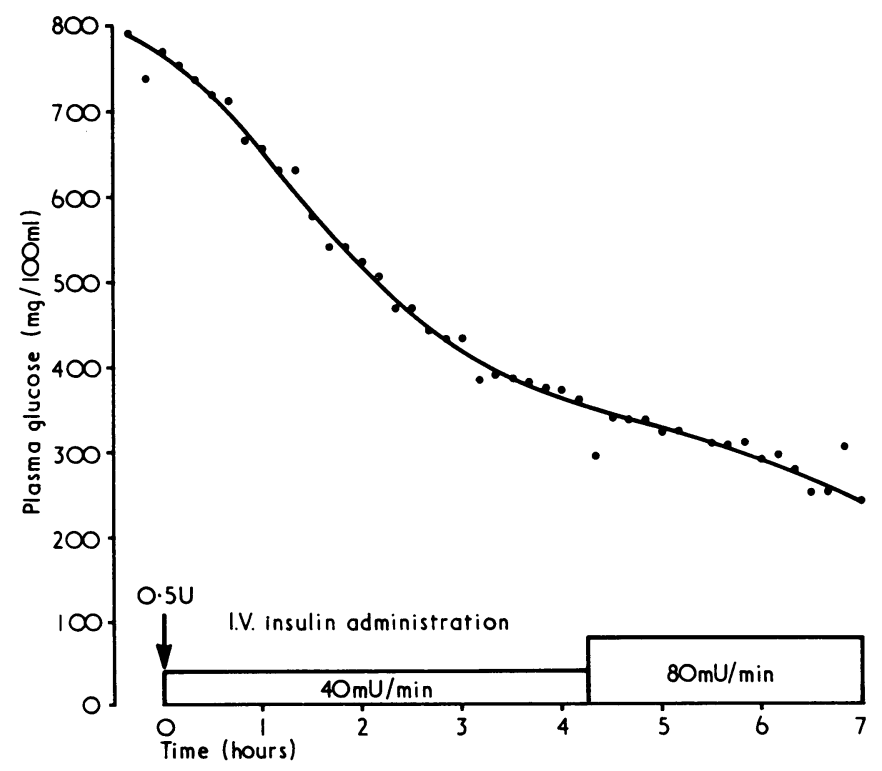

FIG. 2-Plasma glucose response to increases in insulin infusion rates in Case

previous insulin therapy $(P>0.05)$. In two patients the rate of fall in plasma glucose slowed after three to four hours and

Pretreatment Data and Response to Trsatment in 11 Patients treated with Continuous Intravenous Infusion of Insulin

\begin{tabular}{|c|c|c|c|c|c|c|c|c|c|c|c|c|}
\hline \multirow[b]{2}{*}{$\begin{array}{l}\text { Case } \\
\text { No. }\end{array}$} & \multirow[b]{2}{*}{ Age } & \multirow[b]{2}{*}{$\begin{array}{c}\text { Previous } \\
\text { Daily } \\
\text { Insulin } \\
\text { Therapy }\end{array}$} & \multicolumn{5}{|c|}{ Pretreatment Data } & \multicolumn{2}{|c|}{ Insulin Infusion } & \multicolumn{3}{|c|}{ Response to Treatment } \\
\hline & & & $\begin{array}{c}\text { Plasma } \\
\text { Glucose } \\
(\mathrm{mg} / 100 \mathrm{ml})\end{array}$ & $\begin{array}{l}\text { Urinary } \\
\text { Ketones }\end{array}$ & $\underset{\mathrm{pH}}{\text { Arterial }}$ & $\begin{array}{c}\text { Base } \\
\text { Excess } \\
(\mathrm{mEq} / \mathrm{l} .)\end{array}$ & $\underset{\substack{\text { Potassium } \\
(\mathrm{mEq} / \mathrm{l} .)}}{\text { Serum }}$ & $\begin{array}{c}\text { Infusion } \\
\text { Rate } \\
\text { (mU/min) }\end{array}$ & $\underset{\substack{\text { Insulin } \\
(\mu \mathrm{U} / \mathrm{ml})}}{\text { Mean Serum }}$ & $\begin{array}{c}\text { Rate of Fall } \\
\text { of Plasma } \\
\text { Glucose } \\
(\mathrm{mg} / 100 \mathrm{ml} / \\
\mathrm{hr})\end{array}$ & $\begin{array}{c}\text { Time taken } \\
\text { for Glucose } \\
\text { to Reach } \\
200 \mathrm{mg} / 100 \mathrm{ml} \\
\text { (min) }\end{array}$ & $\begin{array}{c}\text { Final Serum } \\
\text { Potassium } \\
(\mathrm{mEq} / \mathrm{l} .)\end{array}$ \\
\hline 1 & 18 & No & 210 & Nil & & & $4 \cdot 5$ & $\begin{array}{l}20 \\
40\end{array}$ & $\begin{array}{l}53 \\
55\end{array}$ & & & \\
\hline 2 & 68 & No & 456 & Nil & 7.44 & -2 & 5.7 & $\begin{array}{l}20 \\
40\end{array}$ & 42 & 69 & 220 & $4 \cdot 8$ \\
\hline 3 & 49 & Yes & 835 & Strong & $7 \cdot 16$ & -19 & 6.8 & $\begin{array}{l}40 \\
80\end{array}$ & $\begin{array}{r}84 \\
>200\end{array}$ & 76 & 420 & $4 \cdot 4$ \\
\hline 4 & 12 & No & 694 & Strong & $7 \cdot 28$ & & $4 \cdot 8$ & 40 & 79 & 117 & 175 & $5 \cdot 2$ \\
\hline 5 & 56 & & 376 & Strong & & & $3 \cdot 4$ & 40 & & 46 & 70 & $3 \cdot 0$ \\
\hline & & $\int(a)$ & 531 & Strong & $6 \cdot 88$ & & $5 \cdot 3$ & 80 & $>200$ & 65 & 250 & $3 \cdot 6$ \\
\hline $\begin{array}{r}6 \\
7 \\
8 \\
9 \\
10 \\
11\end{array}$ & $\begin{array}{l}18 \\
43 \\
17 \\
30 \\
66 \\
42\end{array}$ & $\begin{array}{l}\text { Yes }\{(b) \\
\text { Yes } \\
\text { No } \\
\text { No } \\
\text { No } \\
\text { No }\end{array}$ & $\begin{array}{l}280 \\
509 \\
267 \\
555 \\
492 \\
963\end{array}$ & $\begin{array}{l}\text { Strong } \\
\text { Strong } \\
\text { Strong } \\
\text { Strong } \\
\text { Trace } \\
\text { Trace }\end{array}$ & $\begin{array}{l}7 \cdot 38 \\
7 \cdot 23 \\
7 \cdot 34 \\
7 \cdot 35 \\
7 \cdot 45\end{array}$ & $\begin{array}{r}-9 \\
-17 \\
-5 \\
-13 \\
+7\end{array}$ & $\begin{array}{l}3 \cdot 5 \\
4 \cdot 5 \\
4 \cdot 3 \\
4 \cdot 9 \\
4 \cdot 3 \\
4 \cdot 4\end{array}$ & $\begin{array}{l}100 \\
40 \\
40\end{array}$ & $\begin{array}{r}36 \\
143\end{array}$ & $\begin{array}{r}152 \\
23 \\
50 \\
115 \\
45 \\
77\end{array}$ & $\begin{array}{c}20 \\
390 \\
60 \\
120 \\
360 \\
\text { Infusion } \\
\text { stopped } \\
\text { after } 8 \\
\text { hours }\end{array}$ & $\begin{array}{l}3.3 \\
4.6 \\
3.6 \\
3.6 \\
5.4 \\
2.9\end{array}$ \\
\hline
\end{tabular}


was not accelerated by increasing the infusion rate from 40 $\mathrm{mU} / \mathrm{min}$ to $80 \mathrm{mU} / \mathrm{min}$ (fig. 2) -or to $160 \mathrm{mU} / \mathrm{min}$ in one patient. The mean time taken to achieve a plasma glucose concentration of $200 \mathrm{mg} / 100 \mathrm{ml}$ was 210 minutes. One patient did not reach this level within eight hours and made a slow recovery after beginning subcutaneous insulin.

Stopping the insulin infusion resulted in a decline in serum insulin to basal levels in 10-20 minutes and in no further fall in plasma glucose after 10 minutes. Hypoglycaemia was not found in any patient.

Mean serum potassium fell by a moderate but significant extent during infusion from 4.7 to $4.0 \mathrm{mEq} / 1$. $(P<0.05$ ).

Though cerebrospinal fluid pressure was not monitored, no case of symptomatic cerebral oedema was found despite rapid falls in plasma glucose in some patients.

\section{Discussion}

The intravenous infusion of neutral insulin at rates of $1 \cdot 2,2 \cdot 4$, 4.8 $\mathrm{U} / \mathrm{hr}$ produced satisfactory and occasionally rapid falls in plasma glucose concentration in hyperglycaemic diabetic patients with or without ketoacidosis. The smaller infusion rates of $1.2 \mathrm{U} / \mathrm{hr}$ and $2.4 \mathrm{U} / \mathrm{hr}$ produced mean increases in serum insulin levels to $38 \mu \mathrm{U} / \mathrm{ml}$ and $83 \mu \mathrm{U} / \mathrm{ml}$ respectively, levels that are found physiologically in normal subjects during feeding or oral glucose tolerance testing. As the various metabolic abnormalities in this condition are due to insulin deficiency, and indeed respond to insulin replacement it is reasonable to assume that metabolic recovery will occur more rapidly if insulin is continuously present in the blood and available for tissue utilization. Intravenous boluses of insulin produce high peak serum levels of insulin that fall rapidly so that after 25 minutes the serum insulin concentration is less than $1 \%$ of the peak value in previously untreated patients (Turner et al., 1971). Hence, to maintain physiologically active levels of insulin of no less than $20-30 \mu \mathrm{U} / \mathrm{ml}$ intravenous boluses of insulin must be given every 10 minutes.

The lowest rate of insulin infusion resulting in rapid resolution of diabetic ketoacidosis and hyperglycaemia in this study $-40 \mathrm{mU} / \mathrm{min}$-is of the same order of magnitude as the rate of insulin delivery to the peripheral circulation via the liver in a normal man during a glucose infusion which raises the plasma glucose concentration to $150 \mathrm{mg} / 100 \mathrm{ml}-$ that is, 3.3-37.8 $\mathrm{mU} / \mathrm{min}$ (Stern et al., 1968). The above infusion rate of $40 \mathrm{mU} / \mathrm{min}$ would supply the patient with 58 units of insulin in a 24-hour period, an amount similar to the estimates of a pancreatory insulin secretion rate of $40-60$ units per day (Goldner and Clark, 1944; Yalow and Berson, 1960). Hence the relevance and degree of insulin resistance due to ketones and lower $\mathrm{pH}$ in this condition needs re-examination.

Glucose utilization and inhibition of lipolysis in adipose tissue are responsive to insulin up to a certain saturation concentration of insulin (Hepp et al., 1967). Thus, no further effect can be expected by increasing the serum insulin above the saturation concentration. In-vitro glucose utilization and inhibition of lipolysis in isolated fat cells are saturated at insulin concentrations of about $40 \mu \mathrm{U} / \mathrm{ml}$ and $10 \mu \mathrm{U} /$ $\mathrm{ml}$ respectively (Zierler and Rabinowitz, 1964). Increasing the serum insulin concentration above $80-100 \mu \mathrm{U} / \mathrm{ml}$ is unlikely to have any further beneficial effect.

We believe that the apparent insulin resistance observed in diabetic hyperglycaemia and ketoacidosis is due to four factors. Firstly, intravenous bolus injection of large doses of insulin briefly results in very high serum insulin concentrations, increasing the hepatic and renal clearance of insulin, so that insulin is removed from the circulation before it has any metabolic effect. Secondly, very high concentrations of insulin such as those found after the intravenous bolus injection of large doses of insulin may have deleterious rather than beneficial effects. Lavis and Williams (1973) have shown that though adrenaline-induced lipolysis in isolated rat fat cells is inhibited by insulin at a concentration of $50 \mu \mathrm{U} / \mathrm{ml}$ it continues unabated at the very much higher insulin concentration of $1.000 \mu \mathrm{U} / \mathrm{ml}$. Thirdlv, serum insulin concentration is probably negligible 25 minutes after intravenous bolus injection so that a metabolic "relapse" can occur despite an initial improvement. Finally, the absorption of crystalline (regular) and isophane insulins from subcutaneous injection sites is subject to marked variation in normal people and in newly diagnosed diabetics without impairment of peripheral perfusion (Ginsberg, 1973). Therefore, there may be even wider variation in the absorption of insulin from subcutaneous sites in dehydrated, hyperglycaemic, and ketoacidotic patients.

In this series we did not find the rare complication of cerebral oedema. The absence of svmptomatic cerebral oedema in this series was expected as this is a rare complication of treated ketoacidosis. If cerebral oedema in diabetic ketoacidosis is indeed due to neuronal polyol accumulation from insulin-deficient metabolism, as suggested by Clements et al. (1968), then insulin infusion at such a rate as to keep serum insulin at an effective level should prevent this complication.

Insulin infusion in the treatment of diabetic hyperglycaemia with or without ketoacidosis has several advantages.

Firstly, it is simple to administer and control. Alberti et al. (1973) have criticized insulin infusion as being a logistical possibility only in specialized hospitals. We have found, however, that this therapy is just as effective whether given from a syringe pump or paediatric drip set. Hence it could be given from a paediatric drip set in any hospital where intravenous fluid administration is a common event.

Secondly, there is a low risk of hypoglycaemia, which can be predicted by projection of the rate of fall in plasma glucose.

Thirdly, complicated formulae for insulin doses based on body weight, plasma glucose, or semi-quantitative estimates of plasma ketones are not necessary. The dose of 2.4 units/ hr need not be varied though a smaller dose for small children may be adequate. The timing of subsequent insulin doses is not a problem as the infusion is continued until the plasma glucose has reached a satisfactory level, at which time standard regimens of insulin therapy are instituted along with oral food intake.

Finally, bicarbonate solutions have not been necessary though a study of a larger series of severely acidotic patients is necessary to decide whether alkalis ever have a place in the treatment of diabetic ketoacidosis.

One potential problem with insulin infusion is progressive damage to insulin in the carrier solution over the period of infusion. In a separate study we found a $20 \%$ fall in immunoreactive insulin concentration from $30 \mathrm{mU} / \mathrm{ml}$ to 24 $\mathrm{mU} / \mathrm{ml}$ over eight hours in the physiological saline carrier solution collected at the end of the paediatric drip set. As the recommended infusion rate of $40 \mathrm{mU} / \mathrm{min}$ or $2.4 \mathrm{U} / \mathrm{hr}$ is twice that necessary for therapeutic efficacy such degradation is not likely to be a practical problem. Though immunoreactivity of insulin does not guarantee biological activity there did not seem to be a fall in biological activity with time when using the lowest infusion rate.

Another potential problem is the slight risk of tranmission of hepatitis using albumin solutions. This risk is probably lessened with Australia antigen screening of blood donors. Nevertheless, we are currently studying the use of $3.5 \%$ degraded gelatin solution (Haemaccel, Hoechst), a plasma sustitute, in place of the albumin-saline solution. Haemaccel causes no significant loss of insulin immunoreactivity in solution $(P<0.05)$ and produces a similar decline in plasma glucose when used as an insulin carrier solution in diabetic patients. 
For this form of therapy we recommend that rehydration should be done with fluids that do not contain glucose or large amounts of bicarbonate. A loading dose of 0.5 units of neutral insulin should be given followed by an infusion of neutral insulin at a rate of $40 \mathrm{mU} / \mathrm{min}(2.4$ $\mathrm{U} / \mathrm{hr}$ ) until the plasma glucose has reached a satisfactory level. Increasing the infusion rate is without additional effect, for the reasons outlined above. The infusion solution consists of $500 \mathrm{ml}$ of physiological saline containing $10 \mathrm{~g}$ of human serum albumin and 20 units of neutral insulin. This solution is used over eight hours at $60 \mathrm{ml} / \mathrm{hr}$ and is generally sufficient for completion of therapy. Plasma glucose should be measured every second hour when the previous measurement is above $300 \mathrm{mg} / 100 \mathrm{ml}$ and should be estimated hourly when below this level.

In addition to being a simple form of therapy for all degrees of hyperglycaemia and ketoacidosis low dose insulin infusion may offer a more efficient means of preparing diabetics for surgery.

This work was supported in part by grants from the National Health and Medical Research Council of Australia. We thank the medical staff and the staff of the biochemistry department of St. Vincent's Hospital for their help.

Requests for reprints should be sent to W. Kidson.

\section{References}

Alberti, K. G. M. M., Hockaday, T. D. R., and Turner, R. C. (1973). Lancet, 2, 515.

Beaser, S. B. (1970). In Diabetes Mellitus: Theory and Practice, ed. M. Ellenberg, and H. Rifkin, p. 752. New York, McGraw-Hill.

Bondy, P. K. (1971). In Cecil-Loeb Textbook of Medicine, ed. P. B. Beeson, and W. McDermott, 13th edn., p. 1651. Philadelphia, Saunders.
Bradley, R. F. (1971). In foslin's Diabetes Mellitus, ed. A. Marble, et al., 11th edn., p. 361. Philadelphia, Lea and Febiger.

Clements, R. S., jun., Prockop, L. D., and Winegrad, A. I. (1968). Lancet, 2,384

Danowski, T. S. (1970). In Diabetes Mellitus: Theory and Practice, ed. M. Ellenberg, and H. Rifkin, p. 678. New York, McGraw-Hill.

Ferrebee, J. W., et al. (1951). Endocrinology, 48, 277.

Galloway, J. A., and Shuman, C. R. (1963). American fournal of Medicine, $34,177$.

Genuth, S. M. (1973). Fournal of the American Medical Association, 223, 1348 Ginsberg, S., et al. (1973). Fournal of Clinical Endocrinology and Metabolism, 36, 1175 .

Goldner, M. G., and Clark, D. E. (1944). fournal of Clinical Endocrinology, 4, 194.

Hales, C. N., and Randle, P. J. (1963). Lancet, 1, 200.

Hepp, D., ot al. (1967). Metabolism, 16, 393

Hofman, W. S. (1937). Fournal of Biological Chemistry, 120, 51.

Lavis, V. R., and Williams, R. H. (1973). Diabetes, 22, 629

Rabinowitz, D., et al. (1972). In The Principles and Practice of Medicine, ed. A. M. Harvey, et al., 18th edn., p. 903. New York, AppletonCentury-Crofts.

Randle, P. J. (1965). In On the Nature and Treatment of Diabetes, ed. B. S. Liebel and G. A. Wrenshall, p. 361, Amsterdam, Excerpta Medica Foundation.

Sheldon, J., and Pyke, D. A. (1968). In Clinical Diabetes and its Biochemical Basis, ed. W. G. Oakley, D. A. Pyke, and K. W. Taylor, p. 436. Oxford, Blackwell.

Sonksen, P. H., et al. (1972). Lancet, 2, 155.

Steinke, J., and Thorn, G. W. (1970). In Harrison's Principles of Internal Medicine, ed. M. M. Wintrobe, et al., 6th edn., p. 535. New York, McGraw-Hill.

Stern, M. P., et al. (1968). Fournal of Clinical Investigation, 47, 1947.

Turner, R. C., et al. (1971). Fournal of Clinical Endocrinology and Metabolism, 33, 279

Walker, B. G., et al. (1963). Lancet, 2, 964.

Weisenfeld, S., et al. (1968). Diabetes, 17, 766.

Williams, R. H. (editor) (1968). Textbook of Endocrinology, 4th edn., p. 746 Philadelphia, Saunders.

Williamson, J. R., and Krebs, H. A. (1961). Biochemical fournal, 80, 540.

Winegrad, A. I., and Clements, R. S., jun. (1971). Medical Clinics of North America, 55, 899.

Yalow, R. S., and Berson, S. A. (1960). Fournal of Clinical Investigation, 39, 1157.

Yalow, R. S., and Berson, S. A. (1961). American fournal of Medicine, 31, 882

Zierler, Z. L., and Rabinowitz, D. (1964). Fournal of Clinical Investigation, 43, 950 .

\title{
Continuous Intravenous Infusion of Small Doses of Insulin in Treatment of Diabetic Ketoacidosis
}

\author{
P. F. SEMPLE, C. WHITE, W. G. MANDERSON
}

British Medical fournal, 1974, 2, 694-698

\section{Summary}

Continuous intravenous infusion of small amounts of insulin has been used in the management of a series of patients with diabetic ketoacidosis. In 13 patients with a plasma glucose level on admission of $725 \mathrm{mg} / 100 \mathrm{ml}$ ( \pm 80 S.E. of mean) and an arterial pH of $7.07 \pm 0.05$ a mean loading dose of $6.5 \pm 0.82$ units of soluble insulin was administered intravenously, and thereafter a sustaining infusion of $6.5 \pm \mathbf{0 . 8 2} \mathrm{U} / \mathrm{hr}$ was continued until ketosis was corrected and the plasma glucose fell below $300 \mathrm{mg} / 100 \mathrm{ml}$. The total insulin dose needed to achieve this was $39.2 \pm 6.6$ units given over a 3 to 10 -hour period. Plasma insulin was measured in patients who had not previously received insulin and the mean level at an

The Medical Division, Glasgow Royal Infirmary Glasgow G4 OSF P. F. SEMPLE, M.B., M.R.C.P., Registrar in Medicine

(Present address: M.R.C. Blood Pressure Unit, Western Infirmary, Glasgow)

C. WHITE, M.B., M.R.C.P., Registrar in Medicine

(Present address: Department of Medicine, Manchester Royal Infirmary) W. G. MANDERSON, M.D., F.R.C.P., Consultant Physician infusion rate of $4 \mathrm{U} / \mathrm{hr}$ was $75.6 \pm 8.0 \mu \mathrm{U} / \mathrm{ml}$. Plasma glucose fell at a regular rate of $101 \pm 11 \mathrm{mg} / 100 \mathrm{ml} / \mathrm{hr}$, and ketosis improved in parallel. Plasma potassium was well maintained throughout treatment. This regimen of treatment was clinically effective and simple to follow.

\section{Introduction}

Standard treatment of diabetic ketoacidosis consists of the administration of initial doses of 50-200 units of soluble insulin with a proportion given intramuscularly or subcutaneously and the rest intravenously. In recent years the necessity and desirability of such large doses of insulin have been called into question. Frequent subcutaneous doses of 4-20 units of insulin together with small intravenous boluses have been successfully used in the management of diabetic ketoacidosis (Mohnike et al., 1971). A regimen of frequent doses of 5-10 U/hr of intramuscular insulin has recently been described by Alberti et al. (1973), who found it effective in a series of 14 patients. Good results have been reported in three ketoacidotic patients treated with continuous intravenous infusion of human monocomponent insulin in doses as low as $2.7 \mathrm{U} / \mathrm{hr}$ (Sönksen et al., 1972).

Insulin is necessary in diabetic ketoacidosis to reverse the disturbed intermediary metabolism and to correct the electrolyte imbalance in conjunction with intravenous fluid therapy. A 